\title{
THE SECURITIES ACTS AMENDMENTS OF 1964: SELECTED PROVISIONS AND LEGISLATIVE DEFICIENCIES
}

The Securities Acts Amendments of $1964^{1}$ extend federal regulation of the securities industry far beyond that existing at any time since Congress entered the field of investor protection in 1933. The new legislation attempts to correct deficiencies revealed by thirty years of experience with federal securities regulation. Its most siguificant provisions extend the Securities Exchange Act registration requirements to stocks traded in the over the counter (OTC) market $^{2}$ and subject brokers and dealers in securities to stricter control by the Securities and Exchange Commission (SEC) and the National Association of Securities Dealers (NASD). ${ }^{3}$ Other amendments add new provisions to the Securities Exchange Act $\mathrm{A}^{4}$ and conform old sections to the new regime arising from the requirement that OTC stock issuers register. ${ }^{5}$

This Comment will concentrate on the regulation of OTC companies and securities (1) to ascertain the scope of the 1964 Amendments and (2) to consider the adequacy of coverage in light of the justifications offered for granting exemptions ${ }^{6}$ or favored treatment ${ }^{7}$ to financial institutions and certain business groups. Preceding this discussion is a brief historical background. Following the discussion of OTC securities is an examination of important amendments dealing with disclosure, proxies, and insider trading. ${ }^{8}$

178 Stat. 565 (1964), 15 U.S.C. \$§ 78c(a) (18-21); 1(b) (1)(I-L), (b) (3), (f), (g), (h), (i); $\mathrm{m}(\mathrm{a}) ; \mathrm{n} ; \mathrm{o}(\mathrm{a}),(\mathrm{b}),(\mathrm{c})(4),(5),(\mathrm{d}) ; 0-3$ (b), (d) (2), (g), (b), (k) (2), (l)(1), (2); $p(a),(d),(e) ; t(c) ; w(b) ; f(b)$ [hereinafter cited as Securities Exchange Act], 77d (1964).

2 Securities Exchange Act $\$ 12(\mathrm{~g})$.

3 Securities Exchange Act $\S \S 15,15 \mathrm{~A}$.

4 E.g., Securities Exchange Act $\$ \S 14$ (b),(c) (proxy requirements), 12(b)(1)(I), 12(b)

(3) (disclosure of material contracts).

5 Securities Exchange Act §§ 16(a),(d) (insider trading), 12(f) (unlisted trading), 15(d) (periodic reporting by issuers of securities registered under the Securities Act).

6 Securities Exchange Act $\$ \S 12(\mathrm{~g})(2)(B)$ (mutual funds), 12(g)(2)(C) (savings and loan associations), $12(\mathrm{~g})(2)(\mathrm{D})$ (charitable organizations), $12(\mathrm{~g})(2)(\mathrm{E}),(\mathrm{F})$ (cooperatives).

7 Securities Exchange Act $\$ \$ 12(\mathrm{~g})(2)(\mathrm{G})$ (insurance companies), 12(g)(3) (forcign corporations), 12 (i) (banks).

${ }^{8}$ Not to be discussed are the sections of the Amendments which deal with regulation of broker-dealers, Securities Exchange Act $\$ \S 15,15 \mathrm{~A}$, and the section which amends the Securities Act in the hope of solving the problem of "hot issues." 78 Stat. 580 (1964), 15 U.S.C. $\S 77 \mathrm{~d}(3)$ (1964). Hot issues are first issues of companies primarily in certain "glamour" mdustries. Speculation in them often drives the price of such stocks to unrealistic levels. Hearings on S. 1642 Before a Subcommittee of the Senate Comnittee on Banking and Currency, 88th Cong., 1st Sess. 403-04 (1963) [hereinafter cited as Senate Hearings]. For a detailed discussion of the problem, see Securities and Exchange Commission, Report of the Special Study of the Securities Markets, H.R. Doc. No. 95, 88th Cong., 1st Sess. 487-559 1963 [hereinafter cited as Special Study]. 
HISTORICAL BACKGROUND

Following the stock market crash of 1929 and in the midst of the worst depression in history, Congress passed the Securities Act of $1933^{\circ}$ and the Securities Exchange Act of $1934 .{ }^{10}$ These laws constitute the framework of federal securities regulation. They embody the philosophy that, by and large, the best system of securities regulation is achieved through compelling full disclosure of material financial and other information to investors.

The Securities Act of 1933 regulates public offerings of securities by issuers or persons in a control relationship to the issuers. It prohibits the use of interstate facilities or the mails to market such securities unless the issue is effectively registere ${ }^{11}$ with the SEC $^{12}$ under the 1933 Act. The registration statement must contain all financial and other information necessary for a potential investor to reach an informed investment decision..$^{13}$ A prospectus containing much of the information in the registration statement ${ }^{14}$ must be furmshed to each customer at the time of the first written offer to him $^{15}$ and in no event later than the delivery of a security to a buyer. ${ }^{16}$

The Securities Exchange Act of 1934 regulates the secondary market. Issuers ${ }^{17}$ covered by the Exchange Act must file with the SEC ${ }^{18}$ a registration statement disclosing essential financial and other information. ${ }^{19}$ Section 13 requires that this information be kept up to date by annual and other periodic reports. ${ }^{20}$ Further information must be contained in proxy statements furnished to shareholders in connection with annual meetings. ${ }^{21}$ In addition, the 1934 Act restricts the transactions which

948 Stat. 74, as amended, 15 U.S.C. § 77a-77bbbb (1964) [hereinafter cited as Securities Act of 1933].

1048 Stat. 881 (1934), as amended, 15 U.S.C. \$§ 78a-78hh-1 (1964) [hereinafter cited as Securities Exchange Act].

11 Securities Act of $1933 \S 5(a),(c)$.

12 Securities Act of 1933 \& 6 .

13 Securities Act of $1933 \& 7$, Schedule A.

14 Securities Act of 1933 \$ 10.

15 Securities Act of 1933 \& 5 (b) (1).

16 Securities Act of 1933 \& 5(b)(2).

17 Issuers include not only corporations, but also other business entities such as voting trusts. Securities Exchange Act $\S 3(\mathrm{a})(8)$.

18 Securities Exchange Act $\$ \$ 12(\mathrm{~b}),(\mathrm{g})(1)$. A corporation whose securities are to be traded on a national securities exchange must also file the registration statement with the exchange. Securities Exchange Act \$12(b).

10 Securities Exchange Act $\$ 12(\mathrm{~b})$.

20 Securities Exchange Act $\$ 13$.

21 Securities Exchange Act § 14; 17 C.F.R. § 240.14 (1964). 
officers, directors, and ten per cent shareholders may effect in their company's equity securities. ${ }^{22}$ Prior to the 1964 Amendments the provisions of the Exchange Act applied only to issuers whose stocks were traded on a national securities exchange. ${ }^{23}$ An unlisted company which resorted to the public markets and registered under the 1933 Act was subject to, at most, the reporting requirements of section 13 of the Exchange Act. ${ }^{24}$ Its issues were not subject to the registration, proxy, or insider trading sections of the 1934 Act. Consequently, the protections afforded buyers and sellers of OTC stocks were significantly less than those given persons trading in listed securities. ${ }^{25}$

This double standard of regulation had withstood all previous attempts at rectification..$^{26}$ In September 1961, however, Congress authorized the SEC to study "the adequacy, for the protection of investors, of the rules of the national securities exchanges and national securities associations . . ."27 Results of the study were published in 1963 as the Special Study of the Securities Markets of the Securities and Exchange Commission. ${ }^{28}$ Among the many subjects considered was the need to end the discrimination against traders in OTC stocks by extending to them all the protections of the Exchange Act. ${ }^{20}$ The Study's findings formed the basis of the legislation proposed by the SEC; but there are some important points on which the Commission's recommendations differ from the Study. ${ }^{30}$

22 Securities Exchange Act $\S 16$.

2348 Stat. $892-96$ (1934), as amended by 49 Stat. 1375 (1936), as amended by 68 Stat. 686 (1945).

2449 Stat. 1379 (1936).

25 See 2 Loss, Securities Regulation 1149 (2d ed. 1961).

26 A history of the attempts to bring stocks traded in the OTC market within the Exchange Act is related in Loss, op. cit. supra note 25, at 1149-64.

2775 Stat. 465 (1961). In July 1962 the amount authorized for the study was increased from $\$ 750,000$ to $\$ 950,000$. Securities Exchange Act $\$ 19(d)$. For the reasons which prompted Congress to authorize the study, see H.R. Rep. No. 882, 87th Cong., 1st Sess. 2-5 (1961); Cary, The Special Study of Securities Markets of the Securities and Exchange Commission, 62 MrCE. L. REv. 557, 558 (1964).

28 Special Study.

20 Special Study ch. IX. The language of the bill authorizing the Study does not seem to contemplate consideration of this problem. While the "legislative history made clear that it [Congress] contemplated a very broad study," Special Study ch. I, at 1 , the legislative history speaks of new rules for exchanges and securities associations, but not of new legislation. H.R. REP. No. 882, 87th Cong., 1st Sess. 5 (1961).

30 The preparation of the Study by an independent group, instead of by the SEC, is explained in the Special Study. Special Study, Supp. to pt. 5, at 1-15; cf. Special Study pt. 1, Letter of Transmittal at xvi. For examples of differences between the Special Study and the SEC see text accompanying notes 37-41, 154-57, 205-09, 211-15. 


\section{REGISTRATION OF OVER THE COUNTER STOCKS}

\section{A. General Scope of the Amendments}

New section $12(\mathrm{~g})(1)$ of the Exchange Act requires an issuer having total assets of one million dollars or more to register with the SEC any class of its equity securities held of record by 750 or more shareholders and beginning July 1, 1966, to register any class with as few as 500 shareholders. These requirements apply only to OTC stocks. ${ }^{31}$ Registration for histed securities continues to be secured through the exchanges, which must certify to the SEC that the security has been accepted for histing and registration. ${ }^{32}$ Despite the differences in registration procedure, both listed securities and OTC stocks are now subject to the same reporting, proxy, and insider trading provisions of the Excliange Act. ${ }^{33}$

The legislative history indicates that, unlike many other provisions of the Amendments, the extension of registration to OTC stocks met little opposition. Naturally the stock exchanges favored the legislation, ${ }^{34}$

31 Securities Exchange Act $\S 12(\mathrm{~g})(2)(\mathrm{A})$.

32 Securities Exchange Act $\$ \$ 12(\mathrm{~b})$, (d).

33 Securities Exchange Act $\S \S 13-14,16$. Note, however, the exception to this statement in $\S 16(\mathrm{c})$, which has application only to the OTC market. One indication of the Amendments' impact is the number of corporations affected. It is estimated that at the 750 shareholder level, about 2300 nonbank corporations will be subject to $\$ \S 12,13,14$, and 16 of the Exchange Act as administered by the SEC. Hearings on H.R. 6789, H.R. 6793, and S. 1642 Before a Subcomnittee of the House Committee on Interstate and Foreign Commerce, 88th Cong., 1st and 2nd Sess. pt. 1, at 169, 175 (1963-64) [hereinafter cited as House Hearings]. Of these, however, some 1400 were already reporting to the SEC under Section 15 (d), ibid., because they had made a public offering under the 1933 Act and met the minimum requirements previously set forth in $\S 15$ (d). In addition, about 400 banks will be subject to Exchange Act requirements under the 750 shareholder standard, House Hearings pt. 1, at 169; none of them had previously reported under any section of the Exchange Act. Special Study ch. IX, at 36. At the 500 shareholder level, which becomes effective July 1, 1966, approximately 2900.corporations will be responsible to the SEC; of these, 1600 were previously reporting under section 15 (d). House Hearings pt. 1, at 169, 175. Correspondingly, some 600 banks will have to comply with the Exchange Act when the 500 shareholder level becomes effective. House Hearings pt. 1, at 169. Finally, the bill will make at least 400 insurance companies subject to some regulation, House Hearings pt. 1, at 175; should the states fail to act, the SEC will have jurisdiction, Securities Exchange Act $\$ \S 12(g)(2)(G),(g)(1)$. See text accompanying notes $45-47$ infra.

34 Senate Hearings 79, 141-42, 155, 162, 257. The representative of one exchange stated that he expected the law to result in an acceleration of listings on his exchange. House Hearings pt. 1, at 604. His reason for expecting an acceleration was that an OTC corporation which is required to register is subject to the provisions of the Exchange Act, and so would no longer be deterred from listing by the controls imposed by the Act on listed corporations. Not all registered companies, though, will be able to list on every exchange. The asset and 
as it eliminated the double standard which had plagued them for thirty years. Grudging support was received from the National Association of Securities Dealers ${ }^{35}$ which had previously opposed similar legislation. $^{30}$

Disagreement arose, however, on the scope of coverage. The Special Study recommended eventual inclusion of any class of stock with as few as 300 shareholders irrespective of an issuer's asset value. ${ }^{37}$ The proposed shareholder cut-off point was drawn where the data showed a marked reduction in public interest in a security as measured by trading activity. ${ }^{38}$ In advising against an "asset" test the Study observed that while "larger companies are better able to bear the burden of compliance than smaller ones, any issuer that has considered itself worthy of pubhic financing cannot well be heard to say that its public shareholders are not worthy of statutory protection." ${ }^{\prime 30}$

The NASD, on the other hand, proposed hmits of one thousand stockholders and one million dollars in assets. ${ }^{40}$ Without adducing any evidence to support its position, the Association contended that the disclosure requirements would place too onerous a burden on smaller companies. ${ }^{41}$ The limits finally enacted were those proposed by the SEC and appear to represent a compromise.

One other general qualification was written into section $12(\mathrm{~g})(1)$. The section was made applicable only to an issuer whose business is shareholder thresholds of the amendments, especially after July 1, 1966, are lower than those for listing on some of the exchanges.

\begin{tabular}{|c|c|c|}
\hline \multicolumn{3}{|c|}{ Partial Requirements for a Corporation to List } \\
\hline Exchange & Net Tangible Assets & Shareholders \\
\hline *New York & $\$ 10,000,000$ & $\begin{array}{l}2000,1700 \text { of } \\
\text { which have at } \\
\text { least } 100 \text { shares }\end{array}$ \\
\hline †American & $1,000,000$ & $\begin{array}{l}750,500 \text { of which } \\
\text { have at least } 100 \\
\text { shares }\end{array}$ \\
\hline fMidwest & $2,000,000$ & 1000 \\
\hline \$Pacific & $1,000,000$ & 750 \\
\hline
\end{tabular}

*New York Stock Exchanoe, Company Manuat B-3.

†COOKE, THE STOCK MARKET 214-15 (1964).

¥Pactric Coast Stock Exchange, Rules of tere Board of Governors PR-3.

35 The NASD is the OTC dealers' group.

${ }^{36}$ Hearings on S. 594, S. 1168, and S. 1601 Before a Subcommittee of the Senate Committee on Banking and Currency, 85th Cong., 1st Sess. 182 (1957).

37 Special Study eh. IX, at 62.

38 Special Study ch. IX, at 17-35.

39 Special Study ch. IX, at 33.

40 Senate Hearings 67.

41 Ibid. 
in, or affects, interstate commerce or whose securities are traded by mail or any other means of interstate commerce. Presumably this provision was included to overcome challenges to the constitutionality of the Amendments. As it is virtually impossible to conceive of an issuer with one million dollars in assets and three hundred shareholders not meeting the commerce requirements of $12(\mathrm{~g})(1)$, this qualification is not a himitation' but a breeder of dilatory litigation. Lack of this stricture would not have rendered section $12(\mathrm{~g})(1)$ unconstitutional; Congress may validly legislate if the class of transactions to be regulated has a substantial effect on interstate commerce. ${ }^{42}$

\section{B. Exemptions ${ }^{43}$}

The major controversy relating to registration of OTC stocks resulted from proposals to grant insurance company and bank issues exemption or special treatment. Similar issues arose with respect to cooperatives, foreign issuers, mutual funds, ${ }^{44}$ charitable institutions, and deposits with savings and loan associations. The Congressional response to these problems fails to remedy the serious deficiencies in bank and insurance company securities regulation.

\section{Insurance Companies}

Exeinption of insurance company ${ }^{45}$ issues from registration requirements is conditioned on securities regulation of insurance companies by the states. There are three requirements for exemption: (1) The insurance company must file with the commissioner of insurance of its domiciliary state an annual report which in the Commissioner's opinion substantially conforms to the form prescribed by the National Association of Insurance Commissioners (NAIC $\left.{ }^{46}\right)$. (2) The domiciliary state

12 Wickard v. Filburn, 317 U.S. 111 (1942); cf. Katzenbach v. McClung, 379 U.S. 294 (1965); United States v. Sullivan, 332 U.S. 689 (1948); United States v. Darby, 312 U.S. 100 (1941).

${ }^{43} \mathrm{As}$ already observed, listed securities are not registered under $\$ 12(\mathrm{~g})(1)$, and so the exemptions to be discussed do not affect the requirement that all exchange-traded issues register.

44 This is not to suggest that the mutual fund exemption was unwarranted. See text accompanying note 169 infra.

45 Mutual insurance companies will not be subject to registration. Senate Hearings 355 (Technical Statement of SEC). The noncoverage of mutual insurance companies seems reasonable since the investor is primarily interested in purchasing economical insurance protection rather than making a profitable investment.

46 The voting membership of the NAIC consists of the chief official "who by law is charged with the responsibility of supervising the business of insurance within each state, territory or insular possession of the United States." NAIC Consr. art. 3, in 1 Proceednos

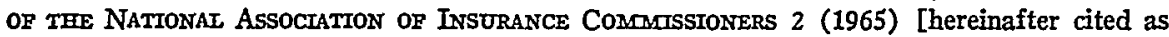
Procerdnoss]. At present there are members from all fifty states, the District of Columbia, Guam, Puerto Rico, and the Virgin Islands. Id. at 27. 
must regulate proxies in accord with regulations prescribed by the NAIC. (3) After July 1, 1966, the domiciliary state must provide for regulation of insider trading "substantially in the manner" set forth in the Exchange Act. ${ }^{47}$

This unusual arrangement is acceptable only if there are sound reasons for departing from the Exchange Act's general pattern of federal regulation and if state regulation will provide insurance company shareholders with protection comparable to that provided by the Exchange Act to holders of other types of securities.

A number of arguments were offered for according special treatment to imsurance companies. The first ${ }^{48}$ was that Congress had, in the McCarran Act of $1946,{ }^{49}$ delegated to the states all governmental regulation of imsurance companies. ${ }^{50}$ Section 2 of the McCarran Act provided: "The busmess of insurance, and every person engaged therein, shall be subject to the laws of the several States which relate to regulation or taxation of such busmess." 151 Since the language quoted may reasonably be read as expressing no intent on the exclusiveness of state regulation, ${ }^{62}$ other indications of congressional purpose must be considered. One indicator is the Act's statement that no Act of Congress should be construed to supersede state insurance laws unless it does so expressly, a statement which contemplates, or at least provides for, future federal regulation. ${ }^{.8}$ Another is the McCarran Act provision that after 1948 insurance compamies would be subject to federal antitrust laws. ${ }^{.4}$ Furthermore, in 1963 about 110 insurance companies ${ }^{56}$ were filing pursuant to section 15(d) of the Exchange Act ${ }^{68}$ and were thus subject to some SEC control. The notion of exclusive state regulation is thus untenable.

47 Securities Exchange Act § 12(g) (2)(G).

$48 \mathrm{It}$ was not pushed very assiduously.

4959 Stat. 33-34 (1945), as amended, 15 U.S.C. $\$ \S 1011-12$ (1964). It was passed after a Supreme Court decision placed insurance companies within Congress' power under the commerce clause, United States v. South-Eastern Underwriters Ass'n, 322 U.S. 533 (1944), overruling sub silentio the dictum in New York Life Ins. Co. v. Deer Lodge County, 231 U.S. 495 (1913), that "contracts of insurance are not commerce at all, neither state nor interstate." Id. at 510 .

50 See House Hearings pt. 2, at 868-69.

5159 Stat. 34 (1945), as amended, 15 U.S.C. § 1012 (1964). See H.R. REP. No. 143, 79th Cong., 1st Sess. (1945).

52 The sponsors of the Act stated its purpose to be to "(1) remove existing doubts as to the right of the states to regulate and tax the business of insurance, and (2), to secure more adequate regulation of such business." Ibid.

5315 U.S.C. $\S 1012$ (b).

5415 U.S.C. \& $1012(\mathrm{~b})$. The significance of this indicator is not reduced by the further provision that federal law only applies to the extent that insurance compames are not so regulated by state law.

55 Senate Hearings 57. There is contradictory testimony on the exact number. At another point in the hearings the number was said to be 169 . House Hearings pt. 1, at 176 n.5.

5648 Stat. 895 (1934), as amended, 15 U.S.C. $\$ 780$ (1964). 
A second theory in support of exemption was that if insurance company accounting practices were made to comply with SEC accounting regulations, the resulting reports would misrepresent the financial condition of the companies, because they would show an accrual of income which might be greater than the amount eventually realized. ${ }^{57}$ In contrast, the NAIC accounting requirements are designed to protect the policy holder but not to accurately reflect financial position. To illustrate, deductions are taken for contingent expenses and for cash expenditures representing expenses not yet imcurred. ${ }^{58}$ In some cases, premium payments are not included in income until liability under the pohicy ceases to exist. 59 The result of this "conservative" approach is to understate income when premium volume is growing and overstate it when premium volume is falling. ${ }^{60}$ Understating mcome prevents unscrupulous promoters from declaring dividends that in a company's first years of operation might leave it unable to cope with unexpectedly high casualty loss payments. ${ }^{61}$ One objection to such practices is that because they are not in accord with accepted accounting principles, ${ }^{62}$ investors will be misinformed about the state of their investment. The insurance industry's accounting procedure also makes comparison of its income producing ability to that of other possible investments difficult if not altogether impossible.

A third insurance industry argument was that compliance with SEC reporting requirements would be too costly; the companies would have to use one method of accounting for the state insurance departments and another for the SEC. ${ }^{63}$ Furthermore, SEC rules generally require independent audits by certified public accountants while insurance company financial reports are prepared by actuaries ${ }^{64}$ who are already in the company's employ. Although some insurance men spoke of 15,000 dollars amually as the cost of compliance with the Exchange Act, ${ }^{65}$ independent witnesses placed the cost figure at 1,500 to 3,000 dollars per year. ${ }^{68}$ To undermine the objection based on cost, the SEC proposed the adoption of a rule allowing the insurance companies to meet the Act's reporting requirements by filing with the SEC the same reports filed with

57 Senate Hearings 239.

58 Schaffer, Audits of Insurance Companies, J. Accountancy, Mar. 1960, p. 44-46.

69 Id. at 46.

60 Id. at $45-46$.

61 See House Hearings pt. 2, at 926, 976.

62 Schaffer, supra note 58, at 48; Broad, The Applicability of Generally Accepted Accounting Principles, J. Accountancy, Sept. 1957, p. 31, 36.

63 House Heariitgs pt. 2, at 976.

64 House Hearings pt. 2, at 986.

65 House Hearings pt. 2, at 976.

${ }^{66}$ See the testimony of Edwin Etherington relying on information obtained from disinterested lawyers and CPA's. Senate Hearings 146. 
the state insurance commissioners plus a few supplementary forms. ${ }^{07}$ This would have eliminated industry objections based upon either a requirement of CPA audits or the need to maintain a set of books using conventional accounting techniques. ${ }^{08}$

Fourth, proponents of exemption questioned the expenditure of federal funds to oversee insurance companies in light of existing control by state insurance departments familiar with insurance problems. ${ }^{00}$ In addition to requiring reports by the companies, the states require periodic inspection by the NAIC. ${ }^{70}$ In meeting this argument, the SEC showed that state regulation is designed to protect policyholders by insuring solvency. ${ }^{71}$ Although solvency is a necessary prerequisite to a profitable investment, it cannot of itself assure investors that they are wise in continuing their investment. Investors need information on finances, major transactions, and material contracts of the corporation. Under the prevailing system of state regulation, however, the financial reports of imsurance companies were the worst of any inajor industry. ${ }^{72}$ Also, most states failed to regulate proxy solicitation and imsider trading. ${ }^{73}$

As the Senate concluded, ${ }^{74}$ the industry argunients do not establisli a case for preferential treatment. But confronted with a determined effort by the insurance lobby, working through the state insurance commissioners, ${ }^{75}$ to stave off federal regulation, the House subcommittee approved the provision for state regulation. The consequences of this choice are reflected both in the method required to avoid federal control and in the model laws and regulations promulgated by the NAIC to fill out the system.

67 House Hearings pt. 2, at 1206-07.

68 "Consistent with the Commission's present practices, the proposed article does not require the reporting of any financial information to the Commission which can not be obtained out of the umiform NAIC annual statement or which is not otherwise readily available." House Hearings pt. 1 , at 178.

60 Senate Hearings 277 ; House Hearings pt. 2, at 880,931 . This objection was also offered in the guise of "double regulation."

70 Senate Hearings 230.

71 House Hearings pt. 1, at 176.

72 Special Study ch. IX, at 40-42; Sencte Hearings 56.

73 Special Study ch. IX, at 40.

74 See S. Rep. No. 379, 88th Cong., 1st Sess. 93-94 (1963).

75 The bulk of the opposition testimony came not from the insurance compamies, though some of their representatives did speak, Senate Hearings 163-65, 228-41, 267-71, 275-77; House Hearings pt. 2, at 924-46, 969-1006, 1052-53, 1055-62, 1378, 1388-89, 1397, 1417-18, but from the state insurance commissioners. This raises the interesting question of why the commissioners engaged in such a protracted fight for exemption when the Senate bill required no action on their part. Since the bulk of their testimony was concerned with the burden $12(\mathrm{~g})(1)$ would place on the insurance companies, the answer seems to be that the commissioners were simply fronting for the insurance companies. Another reasonable possibility is that the commissioners feared a narrowing of their jurisdiction. 
Under the Amendments a state must require the filing by an insurance company of an annual statement prescribed by the NAIC. All states liave agreed to do this. ${ }^{76}$ In addition to detailed financial reports the required statement includes a Stockholder Information Supplement ${ }^{77}$ which asks whether financial statements have been sent to shareholders ${ }^{78}$ and whether proxies were solicited. ${ }^{79}$ The Supplement also requires detailed information on the compensation of insiders ${ }^{80}$ and the dealings of insiders in the stock $^{81}$ of the reporting corporation.

More important to shareholders is the way the other two provisions of the section exempting insurance companies ${ }^{82}$ are being carried out. Implementation of these provisions has only reached the stage of tentative proposals by the NAIC; ${ }^{83}$ but the final rules are likely to be similar, and there is good reason to beheve that the states will follow whatever recommendations are inade. ${ }^{84}$

The Amendments require the state insider trading law to be substantially the same as the federal..$^{85}$ The NAIC's proposed act is therefore a virtual copy of section 16 of the Exchange Act. ${ }^{86}$ However, it is difficult to judge how effective the law would be if enacted, since the NAIC has suggested no regulations. ${ }^{87}$ One consequence is immediately apparent, though. The Exchange Act gives the stockholder of a corporation registered under section 12 nationwide service of process and the right to sue an insider in any federal court district in whicl lie is found, is an imhabitant, or transacts busmess. ${ }^{88}$ However, an insurance company domiciled in a state which has complied with the Amendments' exempting. provisions need not register under section $12 .^{89}$ Its shareholders will there-

76 House Hearings pt. 2, at 893-915.

772 ProceEdnGGS 324-28 (1964).

78 Id. at 325 .

$79 \mathrm{Id}$. at 326.

80 Id. at 326 .

81 Id. at 327.

82 Securities Exchange Act $\S \S 12(\mathrm{~g})(2)$ (G) (ii), (iii).

83 I PROCEEDINGS 152-53, 190-91 (1965).

84 See note 76 supra.

85 Securities Exchange Act $\S 12(\mathrm{~g})(\mathrm{a})(\mathrm{G})$ (iii).

861 ProceEdnNgs 171-73 (1965); An Act Concerning Insider Trading of Domestic Stock Insurance Company Equity Securities $\S \S 1-5$. Its coverage, in fact, is greater than the Exchange Act since it exempts only those insurance companies reporting under the Exchange Act and those which have no class of stock held by one hundred or more persons. Id. at 172; An Act Concerning Insider Trading of Domestic Stock Insurance Equity Securities $§ 7$.

87 The California Department of Insurance has issued proposed regulations. Proposed Rules and Regulations to Cal. Admin. Code, Ch. 5, Title 10, Subch. 5. Compare the broad merger exeniption in proposed Cal. Admin. Code $\$ 2682.3$ (d) with the SEC rule in 17 C.F.R. \& 240.16b-7 (1964).

${ }^{88}$ Securities Exchange Act $\S \S 16(\mathrm{~b}), 27$.

${ }^{89}$ Securities Exchange Act $\S 12(\mathrm{~g})(2)(\mathrm{G})$. 
fore be restricted to bringing suit in those states with which the defendant has had sufficient minimum contacts to satisfy the due process clause, ${ }^{00}$ and further restricted by the extent to which state law conveys jurisdiction over nonresidents. ${ }^{01}$

In contrast, the NAIC has proposed extensive regulations, modeled closely after those of the SEC, to regulate proxy solicitations. ${ }^{02}$ The first three of these define the companies covered, ${ }^{93}$ prohibit solicitations not in comphance with the regulations, ${ }^{24}$ and require certain information be sent shareholders when proxies are not solicited. ${ }^{95}$ Being the foundation for the rest of the regulations, these basic rules should be the minimum components of each state's law authorizing the insurance commissioner to issue regulations.

The tentative NAIC rules have several major flaws. The most serious is the failure to define the scope of the financial statements required to be sent the shareholders. ${ }^{96}$ The required reports are described in the proposed rules by such monstandard uames as "Summary of Operations." There is no assurance that the reports, unlike those prepared by CPA's, will be either complete or accurate..$^{98}$

A second defect is the failure to require that the management include in proxy sohicitations shareholders' proposals for actions to be taken at

90 The possible jurisdiction of the states under the due process clause is narrower than the venue provision of the Exchange Act. In Grossman v. Young, 70 F. Supp. 970 (S.D.N.Y. 1947), the plaintiff was allowed to bring a 16(b) action in the Southern District of New York, where all that occurred was the execution of orders that the defendant, a resident of Michigan, had arranged through a Canadian securities corporation. Note, 60 HARv. L. REv. 1173 (1947). Compare Fisher Governor Co. v. Superior Court of the City and County of San Francisco, 53 Cal. 2d 222, 347 P.2d 1 (1959), in which the court, per Traynor, J., says: "The interest of the state in provicling a forum for its residents . . . or in regulating the business involved ... ; the relative availability of evidence and the burden of defense and prosecution in one place rather than another ... ; the ease of access to an alternative forum ... ; the avoidance of multiplicity of suits and conflicting adjudications ...; and the extent to which the cause of action arose out of defendant's local activities are all relevant . ..," id. at 225-26, 347 P.2d at $3-4$, to determine whether jurisdiction nnay constitutionally be assumed. While Fisher Governor involved a corporation, the limits of jurisdiction over individuals are elearly no.broader. EHRENzWEIG, CONFIICT of Laws 94 (1962 ed.).

91 Not all states have given their courts the full jurisdiction allowed by the due process clause. Even among those states having long arm statutes, there is a great variation in comprehensiveness. See 9B Undroras Laws Annotated 77-81 (Supp. 1964); Comment, 63 Mrch. L. REv. 1028, 1028 n.1, 1035-40 (1965).

921 ProceendNGs 155-70 (1965) (Proposals Regarding Proxies, Consents and Authorizations of Domestic Stock Insurers) [hereinafter cited as NAIC Proxy Regulations].

03 NAIC Proxy Regulations \$ 1.

94 NAIC Proxy Regulations § 2.

05 NAIC Proxy Regulations \& 3.

96 NAIC Proxy Regulations \& 5(2).

07 NAIC Proxy Regulations § 5(2); 2 Procendivgs 325 (1964).

08 See text following note 133 infre. 
shareholder meetings. The subcommittee drafting the regulations decided that there were sufficient state procedures to make such a rule unnecessary, ${ }^{90}$ thereby ignoring both the need which the SEC saw for such a rule $^{100}$ and the difficulties encountered by dissidents under state corporation law. ${ }^{101}$

Another weakness of the NAIC regulations is the failure to impose on management the duty to reveal the interests of the associates ${ }^{102}$ of insiders as well as the interests of the insiders themselves. ${ }^{103}$ This omission presents too many opportunities for deception by dealing through relatives and controlled corporations. ${ }^{104}$

While these and other omissions may be cured in the future, they indicate that the National Association of Insurance Commissioners is inclined toward the most minimal regulation permitted by the Amendments. In view of this fact and the tenuous basis for placing regulation in the hands of the states, the special treatment accorded insurance companies appears ill advised and, in the long run, unlikely to survive.

\section{Banks}

The section of the Amendments dealing with bank securities ${ }^{105}$ does not in terms exempt banks from the requirements of section $12(\mathrm{~g})(1)$. Rather it gives to specified federal banking agencies ${ }^{106}$ the power to admimister sections 12,13, 14(a), 14(c), and 16 of the Exchange Act ${ }^{107}$

99 1 Proceednas 152-53 (1965).

10017 C.F.R. § 240.14a-8 (1964).

101 Cf. Carter v. Portland General Elec. Co., 227 Ore. 401, 362 P.2d 766 (1961); Securities and Exchange Commission, 10th Annual Report, H.R. Doc. No. 158, 79th Cong., Ist Sess. 52 (1945).

102 "The term 'associate,' used to indicate a relationship with any person, means (1) any corporation or organization (other than the issuer or a majority owned subsidiary of the issuer) of which such person is an officer or partner or is, directly or indirectly, the beneficial owner of 10 percent or more of any class of equity securities, (2) any trust or other estate in which such person has a substantial beneficial interest or as to which such person serves as trustee or in a similar fiduciary capacity, and (3) any relative or spouse of such person, or any relative of such spouse, who has the same home as such person or who is a director or officer of the issuer or any of its parents or subsidiaries." 17 C.F.R. \& 240.14a-1(a).

103 NAIC Proxy Regulations Schedule A, Items 4, 6(d).

104 Unlike management, contesting shareholders must disclose the interests of their associates. NAIC Proxy Regulations Schedule B, Items 3(f), 4(b), (c).

105 Securities Exchange Act \& 12 (i).

106 These agencies are: (1) the Comptroller of the Currency for national banks and banks chartered by the District of Columbia, (2) the Federal Reserve Board for all other member banks of the Federal Reserve System, and (3) the FDIC for all other insured banks.

${ }^{107}$ Section 12 prescribes the requirements' for registration under the Exchange Act. Section 13 requires periodic and other reports by companies registered under $\$ 12$. Section 14(a) prohibits the solicitation of proxies from shareholders of registered companies unless made in accordance with the SEC's rules. For a description of \$ 14(c) see text accompanying notes 197-99 infra. Section 16 regulates the trading of a corporation's stock by its directors, officers, and principal shareholders. 
for securities of banks insured with the Federal Deposit Insurance Corporation. Further, these agencies are not to be bound by any "of the rules, regulations, forms, or orders issued or adopted by the Commission . . .."108 This system, unlike that devised for the insurance companies, is to operate under the Exchange Act. The extent of investor protection under this system may be considered from two points of view: (1) what Congress knew when it passed the legislation; and (2) the rules and regulations subsequently issued by the banking agencies.

Congress knew that the Comptroller of the Currency, Mr. James T. Saxon, who has jurisdiction over half the banks covered by the Amendments, ${ }^{109}$ desired a minimum of bank regulation designed for investor protection. ${ }^{110}$. While the Special Study was in preparation Mr. Saxon developed reporting and proxy solicitation, but not insider trading, rules for national banks. ${ }^{111}$ The Study termed these inadequate ${ }^{112}$ and recommended that banks not be exempted froin registration requirements unless protection was provided to investors in bank stocks equivalent to that to be given investors in other types of OTC stocks. ${ }^{113}$ The Study's recommendations, although satisfactory to the Board of Governors of the Federal Reserve System, ${ }^{114}$ met vigorous opposition from the Comptroller. He contended, citing the regulations issued by his office, that no new legislation was necessary to protect investors in bank securities. ${ }^{116} \mathrm{He}$ also argued that the conclusions of the Special Study were wrong because the Study had revealed no bank frauds ${ }^{118}$ and because his office protects investors by examinations and substantive controls of banks. ${ }^{117}$

The Comptroller's arguments are specious. First, his rules were substantially less stringent than those of the SEC. ${ }^{118}$ Second, preventing fraud is only one objective of the Exchange Act; equally important is insuring a complete supply of information in reports and proxy solicita-

108 Securities Exchange Act $\$ 12(\mathrm{i})$.

109 See Special Study ch. IX, at 8; Senate Hearings 180.

110 See the testimony of James Saxon, Senate Hearings 178-79; House Hearings pt. 2, at 1359.

111 Special Study ch. IX, at 39.

112 Ibid.

118 Ibid.

114 Senate Hearings 168-69. The Federal Reserve wanted the Exchange Act administered by the SEC in any event. Ibid.

115 Senate Hearings 178.

116 Ibid. Subsequent events showed that national banks are not immune from gross irregularities. The cases of the San Francisco National Bank and the Brighton (Colo.) National Bank are related in N.Y. Times, Feb. 6, 1965, p. 31, col. 6; id., Feb. 14, 1965, \& 3, p. 1, col. 1.

117 House Hearings pt. 2 , at $1359-60$.

118 Senate Hearings 20-23. 
tions, an area in which banks had perforned badly. ${ }^{119}$ Third, the substantive controls of the Comptroller, like those of the insurance commissioners, while designed to achieve a number of objectives, ${ }^{120}$ do not 'seek to insure the availability of infonnation necessary for intelligent investment.

Under pressure, the SEC proposed that the banking agencies administer the Exchange Act if they so requested. ${ }^{121}$ In response, the Comptroller revised his regulations to give somewhat inore protection to investors and to cover more banks than the bill proposed to cover. ${ }^{122}$ However, these new regulations failed to provide nearly the investor protection afforded by the SEC's regulations. ${ }^{123}$ Because giving many investors insubstantial protection is not significantly more valuable than giving inadequate protection to a few, the increase in the number of banks covered should not have had mucl significance. The House subcommittee, however, recommended inclusion in the Amendments of the provision which vests in the banking agencies the administration of the Exchange Act in regard to bank stocks. ${ }^{123 a}$

The regnlations issued by the banking agencies come disappointingly short of giving adequate protection to investors. One regnlation issued by the Comptroller purports to deny any private right of action by stockholders against a national bank which has violated the regulations. ${ }^{124}$ This regulation will deprive holders of national bank securities of the protection conferred by J.I. Case v. Borak. ${ }^{125}$ In Borak the Supreme Court held that to effectuate the congressional purpose in passing the Exchange Act, shareholders must be given a private riglit of action against a corporation which fails to comply with SEC proxy regulations. While the Comptroller may issue regulations defining the requirements of a proxy solicitation and the manner in which it is to be conducted, ${ }^{126}$ he lacks the power to issue valid rules negating the fundamental objectives of the Exchange Act. ${ }^{127}$ Further, the no-private-action rule demes shareholders in national banks relief afforded to lolders of all other types of securities covered by section $12(\mathrm{~g})(1)$. Since there is no indication that bank stock owners can either vote proxies more

110 Special Study ch. IX, at 38-39.

120 Senate Hearings 20.

121 Senate Hearings 54. The Federal Reserve would thus have been able to leave administration of the Exchange Act as to its banks with the SEC. See note 116 supra.

122 Senate Hearings 172-75.

128 House Hearings pt. 1, at 118.

123a H.R. REP. No. 1418, 88th Cong., 2d Sess. 8-9 (1964).

12412 C.F.R. \& 10.2 (1965).

125377 U.S. 426 (1964).

126 Securities Exchange Act $\S 14(\mathrm{a})$.

127 See Greene v. Dietz, 247 F.2d 689, 692 (2d Cir. 1957) (dictum). 
intelligently than other types of investors who have incomplete or erroneous information or undo the results of an improper proxy solicitation by some other method, the Comptroller's rule creates an arbitrary discrimination against bank stock owners.

Another of the Comptroller's regulations requires that proxy solicitations for a meeting at which directors are to be elected contain the name, age, and principal occupation of a nominee for director, plus the principal office he holds with the bank, if any. ${ }^{128}$ The SEC regulations, on the other hand, compel the following additional information about the nominee: any position he holds with the corporation, how long he has been a director, how many shares of each class of stock of the corporation or any of its subsidiaries he owns, whether he is, together with any associates, the beneficial owner of ten per cent or more of any class of stock of the corporation or any of its subsidiaries, whether he has an understanding about his election with any other person, and the name and business of his employers for the past five years. ${ }^{120}$ Aside from the desirability of consistency, the additional information required by the SEC is exactly the type an intelligent investor wants to know in deciding whether a director is likely to represent the interest of the shareholders who elect him. Similarly, the Comptroller's regulation on compensation to officers and directors requires disclosure only of the "direct aggregate remuneration paid to all principal officers of the bank as a group without naming them, ${ }^{\prime 130}$ plus any amount set aside in the past year for pension or retirement benefits. ${ }^{131}$ By contrast, the SEC requires detailed information regarding all benefits conferred by the corporation or its subsidiaries on each director and on the three highest paid officers with salaries above 30,000 dollars as well as on all directors and officers as a group..$^{132}$ In the case of directors the added information, especially that about material transactions, is important in determining the directors' self-interest. The information on fringe benefit compensation is necessary for the shareholders to determine whether the directors are wasting the investor's money on unreasonable officer remuneration.

Although the regulations promulgated by the Federal Reserve System more closely conforın to SEC requirements, one weakness seems

12812 C.F.R. \& 11, Schedule A (1965).

12917 C.F.R. \& 240, Schedule 14A, Item 6 (1964).

13012 C.F.R. $\$ 11$, Schedule A, Item 3(a) (1965).

13112 C.F.R. \& 11, Schedule A, Item 3(b) (1965).

13217 C.F.R. \$ 240, Schedule 14A, Item 7 (1964). The data required are: direct remuneration, the amount set aside for pensions and expected benefits on retirement, other proposed future payments, stock options granted or exercised in the past fiscal year, indebtedness to the corporation and the rate of interest charged, and material transactions with the corporation or its subsidiaries. 
apparent; the rules do not require independent audits. ${ }^{133}$ Preparation of financial statements by certified public accountants protects shareholders in several ways. First, it assures the investor that the reports he receives accurately reflect the company's financial condition on a consistent basis. Second, it permits comparison with companies in other industries ${ }^{134}$ who, because of SEC requirements, will have somewhat uniform accounting standards. ${ }^{135}$ Third, an outside audit by an independent public accountant is far more rehable than an inside audit by bank employees. The importance of audits by independent accountants was recognized in the proposed Federal Reserve regulations. ${ }^{136}$ However, the banks secured omission of that requirement ${ }^{137}$ by two arguments. They contended first that independent audits are unnecessary ${ }^{138}$ because the Federal Reserve conducts regular audits of member banks. These investigations are, however, designed to prevent dishonesty, and do not satisfy the stockholders' need for meaningful financial statements. ${ }^{139}$ The opponents of independent audits also argued that it would be unfair for the Federal Reserve to require of state banks what the Comptroller was not requiring of national banks. ${ }^{140}$ If the state banks meant by this that the expense of audits would put them at a significant competitive disadvantage, they ignored the evidence that audits would cost only 1,500 to 3,000 dollars annually. ${ }^{141}$ Perhaps the banks only meant to suggest that they would be less able to conceal questionable ${ }^{142}$ dealings from passive investors.

133 SEC rules generally require audits by certified public accountants. 17 C.F.R. \$ 210.1-01(a)(3) (1964).

134 When the Bank of California employed a public accounting firm to audit its books, Glenn Mowry, a vice president of the bank, said: "We believe that so long as banks compete with industry for capital funds, we must play by the same ground rules as other corporations." San Francisco Chromicle, Oct. I, 1965, p. 48, col. 1.

135 In some instances, lowever, corporations do not follow normal accounting procedures. See, e.g., American Institute of Accountants Committee on Accounting Procedure, Long-term Construction-type Contracts, Accounting Research Bull. Oct., 1955, p. 45.

136 See 29 Fed. Reg. 12130 (\$ 206.4(e)), 12929 (\$ 206.7) (1964).

13730 Fed. Reg. 36 (1965).

138 P-H Fed. Control of Banking, Rep. Bull. Vol. III, No. 10, Jan. 13, 1965, at 1.

$139 \mathrm{Had}$ the financial reports of the Bank of California for 1964, see note 134 supra, been prepared by a CPA, they would have shown a small reduction in net earnings. As the bank's president, Charles de Brettville, said: "Bank financial statements, earnings reports, and the like, required by government regulatory authorities have been oriented almost solely to the interest and protection of depositors. We recognize such an obligation to our depositors, but our adoption of an outside audit recognizes an equal obhgation to our shareholders ...." San Francisco Chromicle, Oct. 1, 1965, p. 48, col. 1.

140 P-H Fed. Controt of Bankivg, Rep. Bull. Vol. III, No. 10, Jan. 13, 1965, at 1.

141 See text accompanying note 72 supra.

142 A CPA audit would disclose two kinds of questionable deakings which might otherwise be concealed. One is a procedure which inaccurately reflects income; for example, the use of unreasonable depreciation methods. The other is a self-dealing contract hetween a bank and one of its officers, such as a long term lease. 
The regulations issued by the banking agencies thus fail to carry out the disclosure philosophy of the Exchange Act as effectively as those issued by the SEC. The banking agencies' systems protect against fraud, but deny shareholders a satisfactory opportunity to evaluate the policies and programs of the directors.

\section{Co-operatives}

Two sections of the Amendments exempt from registration requirements the securities of certain co-operatives. One section exempts securities issued by a co-operative providing goods or services primarily to members if the shares are: (1) non-dividend paying, (2) sold only to persons who make purchases from the issuer, and (3) nontransferable or transferable only to a successor to the issuer's services. ${ }^{143}$ The other section $^{144}$ exempts issues of co-operatives defined in the Agricultural Marketing Act of $1929 .{ }^{145}$

The exemption first mentioned is derived from a proposal by the Rural Electric Cooperative Association. ${ }^{146}$ SEC support was received because co-operative securities display no trading activity, ${ }^{147}$ a fact that indicates little public investor interest. However, at least five hundred persons have funds imvested in any organization covered by the Amendments. These investors may not require all of the Exchange Act's protections, but to deny them the benefit of the reporting, proxy, and insider trading provisions is to deny that a co-operative may have an mcompetent or unscrupulous management. The United States government guards against such possibilities in the case of electric co-operatives; ${ }^{148}$ but the language of the statute includes many other co-operatives which may not receive government supervision. Nor does the coincidence of equity holders with member-buyers eliminate the need for nonexemption, ${ }^{149}$ because the self-interest of management competes with the interests of both groups. Althouglr management cannot engage in share manipulation ${ }^{150}$ full and accurate disclosure of material information would

143 Securities Exchange Act $\S 12(\mathrm{~g})(2)(\mathrm{F})$.

144 Securities Exchange Act $\$ 12(\mathrm{~g})(2)(\mathrm{E})$.

14546 Stat. 18 (1929), as amended, 12 U.S.C. $\$ 1141 \mathrm{j}(\mathrm{a})$ (1964).

146 House Hearings pt. 2, at 859-60. Neither this co-operative exemption nor the other was approved by the Senate. S. REP. No. 379, 88th Cong., 1st Sess. 93-94. House subcommittee approval seems to have occurred because the SEC first expressed an intent to exempt by rule the issues involved and then proposed language for an exempting section. House Hearings pt. 2, at 859-60.

147 Id. pt. 1 , at $275-76$.

148 See $i d$. pt. 2, at 856-58.

149 The Rural Electric Cooperative Association suggested such coincidence, in addition to other factors, did eliminate the need for nonexemption. Id. pt. 2, at 861 .

150 Securities Exchange Act $\S 12(\mathrm{~g})(2)(\mathrm{F})$. 
aid shareholders in co-operatives to discover management and director inefficiency and self-dealing. The need for this protection in a business having one million dollars in assets seems to outweigh the expense imvolved.

Exemption of co-operatives defined in the Agricultural Marketing Act lack whatever justification for exemption inheres in nontransferabihty. Because the stock of these co-ops has virtually free transferability and may earn dividends of as much as eight per cent per year, ${ }^{151}$ there is a substantial incentive for trading in membership shares based on inside information. Granted certain protections against this practice were incorporated into the Marketing Act. For example, the Act prohibits certain insiders from disclosing insider information, ${ }^{152}$ and it prohibits certain outsiders from speculating in membership interests. ${ }^{153}$ Yet these restrictions leave the subject co-ops unprotected against insider selfdealings of the type forseen by Exchange Act sections 16(b) and 16 (c).

\section{Foreign Issuers}

In accordance with the Special Study's recommendations ${ }^{154}$ the Amendments permit the SEC to exempt any foreign security if exemption is: (1) in the public interest and (2) consistent with the protection of imvestors. ${ }^{155}$ Under the plan favored by the SEC, but rejected by Congress, ${ }^{156}$ securities of foreign issuers would have received a blanket exemption whicl the Commission could withdraw from any security if there existed a sufficient public market for that security and if exemption was not in the public interest. ${ }^{157}$

The SEC propounded several arguments in support of its approach. First, it noted the difficulty of enforcing the provisions of the Exchange Act against a foreign issuer having only minimal contacts with the United States. ${ }^{158}$ That argument is irrelevant; the enforcement problem

15146 Stat. 18 (1929), as amended, 12 U.S.C. $\$ 1141 j$ (a) (1964).

15246 Stat. 18 (1929), 12 U.S.C. \& 1141 (c) (1964).

15346 Stat. 18 (1929), 12 U.S.C. § 1141 (b) (1964).

154 Special Study ch. IX, at 63.

155 Securities Exchange Act $\$ 12(\mathrm{~g})(3)$.

158 It was approved by the Senate subcommittee. S. REP. No. 379, 88th Cong., 1st Sess. 29-30 (1964).

157 Senate Hearings 58.

158 Senate Hearings 58; House Hearings pt. 2, at 1284, 1287. The difficulties contemplated by the SEC have been lessened by the decision in United States v. First Nat'l City Bank, 379 U.S. 378 (1965). In that case the Internal Revenue Service, having made tax claims against Omar, S.A., a Uraguayan corporation, served the City Bank, in whose Montevideo branch Omar maintained a deposit, with notices of a tax lien and of an action for an injunction to prevent the transfer of the property in Omar's account. Omar, who had transacted some business in New York, was not served. The district court granted the injunction sought by the IRS and was upheld by the Supreme Court. The Court reasoned 
would be the same whether an issuer was required to register under the statute's general provisions or under an exception to a blanket foreign security exemption. Second, the SEC argued that it sought not to create a special privilege for foreign issuers, but only to continue the existing exclusion from Exchange Act requirements. ${ }^{150}$ The new amendments were, however, expressly designed to cover stocks not previously covered. Third, the Commission suggested that the Special Study's version would hurt the American investor because it would make it harder to trade stock of a foreign issuer which was required to register, but failed to do so. ${ }^{180}$ The Act does not, however, proscribe trading in noncomplying issues, nor even require the Commission to stop trading in such issues. Nor did the SEC support its assertion that dealers would be reluctant to trade in a security when an obligation under the Amendments was not being fulfilled. ${ }^{161}$

Finally, the SEC argued that if written as the Special Study proposed, the act would place a greater administrative burden on the SEC. ${ }^{162}$ The validity of this point turns on whether there would be more applications for exemptions if all securities were covered than there would be requests for coverage by shareholders if the starting point were exemption for all foreign issues. In writing the law to allow only specific exemptions from registration the House subcommittee said that the procedure adopted would involve less work for the SEC than the alternative. ${ }^{163}$ The subcommittee's position is tenuous; almost every foreign

that in personam jurisdiction over the City Bank had been obtained, and therefore the court's orders applied as fully to the Montevideo branch over which defendant maintained managerial control as to the home office. However, the Court also indicated that the case would be quite different if Omar were beyond due process hmits on jurisdiction. Id. at 381 .

As long as the Court is not inclined to limit the City Bank case to its facts, the SEC will be able to effectuate compliance by foreign issuers with the registration, reporting, and proxy provisions of the Excliange Act by cutting off the corporations' use of American credit, thus hampering, if not totally impeding, their ability to do business witb the United States. Even those foreign, \& $12(\mathrm{~g})$ corporations having only minimal contacts with the United States could be inconvenienced to the extent that they had funds in branclies of United States based banks. A basis for impounding a corporation's bank deposits can be found in the section of the Excliange Act imposing monetary penalties for noncompliance with the Act. Securities Excliange Act \& 32 .

The ability of shareholders to use these inethods to prevent unlawful insider trading is limited hecause directors of foreign corporations are less likely to have both contacts with the Umited States and deposits in American banks. The SEC could aid shareholders, however, by making consent to suit in the United States hy a corporation's directors a part of the registration and reporting requirements for foreign corporations. Cf. Nat'I Equip. Rental, Ltd. v. Szukhent, 375 U.S. 311 (1964).

150 See House Hearings pt. 2, at 1286-88.

160 House Hearings pt. 2, at 1287.

161 See House Hearings pt. 2, at 1288.

162 See House Hearings pt. 2, at 1289-90, 1348-49.

163 H.R. ReP. No. 1418, 88th Cong., 2d Sess. 11 (1964). 
corporation will probably seek exemption. When a suggestion to this effect was made on the floor of the House, the SEC indicated its intention to grant foreign securities a blanket exemption for a limited period. ${ }^{164}$ The SEC has subsequently promulgated a rule granting a one-year exemption. ${ }^{165}$ The SEC rule, in effect, makes the bill operate as if written the way the Commission sought, without, however, providing for the

164110 Cong. REc. 17325 (daily ed. Aug. 4, 1964).

10517 C.F.R. \& 240.12g3-1 (1965). On November 16, 1965, after this Comment had been set into type, the SEC issued proposed rules with respect to foreign issuers whose securities are traded in the OTC market. 30 Fed. Reg. 14737-42, 14743-48 (1965). The new rules would withdraw the blanket exemption for foreign issuers, referred to above. $30 \mathrm{Fed}$. Reg. 14740 (1965). The proposed rules would substitute the following regulatory scheme for private foreign issuers (except North American and Cuban issuers) covered by $\S 12(\mathrm{~g})$ :

A foreign OTC issuer is completely exempted from the Exchange Act unless it has 300 or more shareholders resident in the United States. 30 Fed. Reg. 14741 (1965). If required to register, the foreign issuer may do so by furnishing the SEC "whatever information the issuer, during the past year, (i) was required to make public in the country of its domicile pursuant to the law of that country, (ii) filed with a stock exchange on which its securities are traded and which was made public by the exchange with which the issuer filed the information, or (iii) distributed to its security holders." 30 Fed. Reg. 14744 (1965). If that material does not include an income statement, a position statement, a brief description of the issuer's business, and an outline of the securities holders' rights, such information inust also be furnished. Ibid. Reporting pursuant to Exchange Act $\S 13$ is accomplished by filing items (i), (ii), and (iii) above and yearly income and position statements. 30 Fed. Reg. 14748 (1965). Even if not completely exempted from the Exchange Act's registration requirements, the issuer will be exempted from the proxy and insider trading controls of $\S \S 14$ (c) and 16 unless more than fifty per cent of its voting securities are owned by residents of the United States or its "principal business" is conducted in the Umited States. 30 Fed. Reg. 14741 (1965). Furthermore, under certain circumstances proxy solicitations will not be subject to SEC regulations. Ibid.

These are minimal regulations at best. The reporting requirements are stricter for a foreign issuer who is covered only by $\S 15$ (d) than for an issuer who is subject to $\S 12(\mathrm{~g})$. See 30 Fed. Reg. 14743, 14746, 14748 (1965). And financial reports for a registered foreign OTC issuer need not be independently audited in accordance with the standards of the issuer's domicile. 30 Fed. Reg. 14743-44 (1965). In addition, the residence of twenty-five per cent of all issuer's shareholders in the United States should be sufficient to make it subject to $\$ \$ 14$ (c) and 16. Cf. Jennings \& Marse, Securities Regulation 559 (1963).

It also appears that the SEC anticipates noncompliance by foreign issuers with even the miuimal regulations proposed. The Commission is therefore making it a manipulative, deceptive, or fraudulent device or contrivance (as defined by $\S 15(\mathrm{c})(1)$ ) for a broker or dealer not to inform a potential purchaser of a foreign issuer's securities that the issuer is on the SEC's list of noncomplying foreign issuers. 30 Fed. Reg. 14741 (1965). In addition, market makers in the security (defined in 17 C.F.R. $\S 240.17 \mathrm{a}-9(\mathrm{f})(1)$ ) are subject to a duty. They must supply to the SEC public documents or reports about the issuer's financial and business position which (1) come into their possession and (2) were prepared by the issuer or which the market maker has reasonable grounds to believe were prepared by or for the issuer. 30 Fed. Reg. 14741 (1965).

Finally, none of the information furnished to the SEC in comection with the registration or reporting of foreign issuers covered by $\$ 12(\mathrm{~g})$ will be considered "filed" within the meaning of $\$ 18$ of the Exchange Act. 30 Fed. Reg. 14741, 14742, 14743, 14748 (1965). Thus, buyers and sellers are deprived of $\S 18$ 's remedies for false and misleading statements. On the validity of such a rule see note 168 infra. 
possibility of exceptions. ${ }^{166}$ Since the House subcommittee clearly did not believe that a blanket exemption was "in the public interest" and "consistent with the protection of investors," it is impossible to reconcile the SEC rule with Congress' intentions. Sliould the SEC try to extend the blanket exemption or grant an exemption to any large number of foreign stocks, a court test of sucli a regulation seems warranted. Conceivably, an owner of shares in a foreign corporation could sue to recover damages from insiders for violation of section 16(b) of the Exchange Act, ${ }^{167}$ claiming that the corporation's purported SEC exemption is beyond the Commission's power to grant. ${ }^{168}$

\section{Other Exemptions}

The Amendments also contain less controversial exemptions. Mutual funds ${ }^{169}$ are exempted from the Excliange Act because they are subject to comparable regulation by the SEC under the Investment Company Act. ${ }^{170}$ Charities $^{171}$ are exempted on the theory that there is normally no trading interest in their securities. ${ }^{172}$ And a provision exempting deposits with savings and loan associations and similar institutions ${ }^{173}$ was necessary because the institutions involved refer to savings accounts with them as "shares." The exemption does not apply, however, to any true equity interest representing nonwithdrawable capital.

Finally, the SEC may exempt any issuer from sections 13,14 , or 15 (d) ${ }^{174}$ and exempt insiders from section 16 if after a hearing the exemption is found to be consistent with the public interest and the protection of investors. ${ }^{175}$ The statute suggests that a decision to exempt might be warranted if there is insubstantial trading in the stock. ${ }^{170}$

Registration of any class of security may also be terminated if the issuer certifies to the Commission that the number of holders of record

166 The SEC might have authority for its actions under Securities Exchange Act $\$ 12(\mathrm{~g})(1)$, but in explaining its power to issue the regulation no mention is made of 12(g) (1). 29 Fed. Reg. 9641 (1964).

167 Securities Exchange Act $\$ 16(\mathrm{~b})$.

168 See Greene v. Dietz, 247 F.2d 689 (2d Cir. 1957). Defendants relying in good faith on the exemption will, however, have a good defense. Securities Exchange Act $\$ 23$ (a).

169 Securities Exchange Act $\S 12(\mathrm{~g})(2)(B)$.

17054 Stat. 789-847 (1940), as amended, 15 U.S.C. \& 80a (1964).

171 Securities Exchange Act $\S 12(g)(2)(D)$.

172 Senate Hearings 355.

173 Securities Exchange Act $\$ 12$ (g) (2)(C).

174 For the functions of $\$ 13$ and 14 see note 107 supra. Section $15(d)$ requires certain registrants under the Securities Act of 1933 to report persuant to $\S 13$ of the Exchange Act. 175 Securities Exchange Act $\S 12(\mathrm{~h})$.

176 Securities Exchange Act $\S 12(\mathrm{~h})$. Exemptions have been granted to: (1) nontransferable interests in stock, pension, profit sharing, and similar plans, and (2) bank common trust funds. 30 Fed. Reg. 6115 (1965). 
of that security has fallen to less than three hundred. ${ }^{177}$ Foreseeing that the minimum number of shareholders for requiring registration and the terminus number of three hundred might be the bases of attempts to avoid registration, Congress defined a "class" to include all securities "of substantially similar character and the holders of which enjoy substantially similar rights and privileges."118 The Amendments also permit the Commission to define "total assets" and "held of record."179 Under new SEC rules "total assets" are the assets reported to the SEC in the company's position statement or in the statement for the company and its subsidiaries, whichever is greater. ${ }^{180}$ "Held of record" is defined so as to prevent circumventing the statute by transferring shares to a common trustee. ${ }^{181}$ The rule does not, however, treat a husband and wife holding as co-owners as different holders of record. ${ }^{182}$

III

SOME OTHER MAJOR CHANGES IN THE EXCHANGE ACT

\section{A. Reporting Requirements}

Section 12 (b) (1) has been amended to require registrants under the Exchange Act to file information on material contracts not made in the ordinary course of business, including inaterial patents. ${ }^{183}$ Disclosure of these transactions was already required for registration under the Securities Act; ${ }^{184}$ the amendment to the Exchange Act follows a recommendation of the Special Study that registration under the two acts be made as similar as possible. ${ }^{185}$ To prevent this provision from placing an undue burden on a corporation, the Commission is prohibited from seeking information regarding contracts made more than two years before registration. ${ }^{186}$ A company is also protected by the SEC's general power to keep confidential information secret. ${ }^{187}$

\section{B. Proxies: Amendments to Section 14}

New section 14(b) makes it unlawful for a record owner who is not also the beneficial owner to give or refrain from giving proxies except

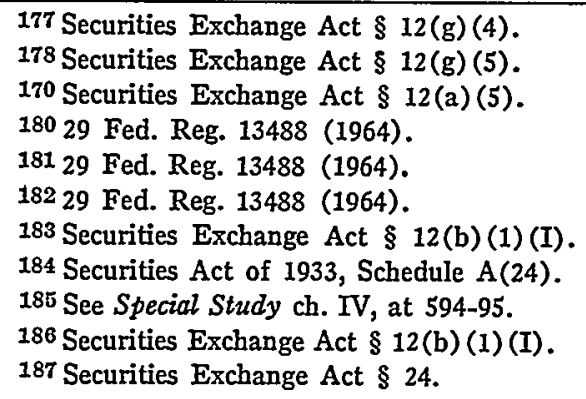


in accordance with SEC rules. ${ }^{188}$ Section 14 (c) requires that prior to a shareholders' meeting for which management does not solicit proxies, a corporation must supply shareholders with information equivalent to that which would have been sent had proxies been solicited. ${ }^{180}$

The amendment to section 14.(b) attempts to reach a problem generated by the common situation of a broker holding securities in street name. ${ }^{100}$ In the absence of a law to the contrary, the broker, having legal title to the securities, could give proxies for all his street name shares. ${ }^{101}$ Former section 14(b) prohibited brokers from giving proxies unless they acted in accordance with SEC rules. ${ }^{102}$ The SEC did not, however, feel it had power to deal with brokers who refrained from giving proxies at all. ${ }^{103}$ As a result, the SEC issued no rules regulating the giving of proxies becauise it thought such rules would have no practical effect other than to induce a broker to do nothing with the proxy solicitations he received. ${ }^{104}$ The new law, therefore, also prohibits a broker from refraining to give proxies unless lie is acting in accordance with SEC rules.

To insure that the legislative change has the desired effect, the SEC has proposed a new regulation. ${ }^{105}$ The regulation first requires a corporation to ask each shareholder of record whom the corporation knows holds securities for the benefit of others how many beneficial owners he represents. The corporation must then send that number of sets of proxy materials to the record holder and inust pay him for forwarding the materials to the beneficial owners. The regulation seems, however, to require actual knowledge and not just notice ${ }^{106}$ that a record holder is not

188 Securities Exchange Act \$ 14(b).

189 Securities Exchange Act \& 14(c).

$100 \mathrm{~A}$ street name is the name in which a broker takes legal title to stock which he is holding for the account of a customer. The procedure is used because it facilitates customer transactions involving the stock or because the stock is held on margin accounts. 2 Loss, Securities Regulation 925 (2d ed. 1961).

191 The magnitude of this problem is indicated by the fact that in 1959 about $8 \%$ of all securities were held in street name, while an additional $18 \%$ were in the names of nominees and fiduciaries. NEW York StOcK Exchange, Share OWNERSHIP IN AMTERICA: 1959 34 (1959).

10248 Stat. 895 (1934).

193 House Hearings pt. 1, at 182.

104 Senate Hearings 401.

19530 Fed. Reg. 711 (1965).

106 The difference is between knowing in fact (actual knowledge) and having reasonable cause to beheve (notice), A regulation requiring only notice would cause corporations to make inquiry of sbareholders who were broker-dealers, trust compames, or other financial institutions. While those businesses might be holding the stock for their own accounts, the likelihood that at least some of the shares would be held for others' accounts should constitute notice to the issuer that the record owner is not the beneficial owner. Determining which shares are held by broker-dealers should present hittle problem, since broker-dealers must be registered with the SEC. Securities Exchange Act $\$ \S 12$ (a), 15(a)(1). Changing the 
the beneficial owner. Therefore, the rule will be ineffective unless for some unusual reason the corporate shareholder list indicates which owners have legal but not equitable title.

Section 14(c), requiring that shareholders be supplied with proxy . type information before all stockholder meetings, is designed to prevent management from acting against the wishes of an absent majority of the shareholders. ${ }^{197}$ Prior to its enactment, only the New York Stock Exchange had had such a rule. ${ }^{198}$ For the new provision to be effective, the SEC should adopt a regulation compelling the required information to be sent as far in advance of the meeting as necessary to enable dissidents to sohcit proxies opposing the action proposed to be taken at the meeting. ${ }^{199}$ Unless a regulation of this sort is adopted, section 14(c) may help create a highly informed but virtually impotent group of investors.

\section{Insider Trading}

Protection against insider trading, provided by section 16,200 is a inajor function of the Exchange Act. The section 16 requirement that insiders report changes in their stock ownership has been amended to cover OTC securities, ${ }^{201}$ thus extending the short-term profits and short sales restrictions to the OTC market. ${ }^{202}$

An entirely new amendment to section 16 exempts from its operation transactions by a dealer in the OTC market which are made "in the

regulation to require only notice would not help all beneficial owners, of course, since for some the record owner would be a private individual.

197 A new section of the Exchange Act, Securities Exchange Act $\S 15(c)(4)$, permits the SEC to order compliance with $\S 12,13$, and 15(d), but not $\S 14(\mathrm{c})$. As $\S 14$ (c) is a positive obligation on the corporation and not just a mode to be followed if action is taken, means should be provided for SEC enforcement. The omission seems to have heen an oversight.

108 See S. Rep. No. 379, 88th Cong., 1st Sess. 24; New York Stock Exchange, Company Mandar A-134. The American Stock Exchange had embarked on a program to get such a rule. S. REP. No. 379 supra at 24.

109 This period may have to be longer than the period of ahout one month which managements usually allow between the solicitation of proxies and the shareholders' meeting. Dissidents would find it diffcult, if not impossible, to solicit proxies within a thirty-day period considering that all proxy soliticitation materials must be filed with the SEC ten days before they are sent to shareholders. 17 C.F.R. \$ 240.14a-6(a) (1964). An overly long interval, on the other hand, would cause the management's information to be stale by meeting time. A forty or even sixty-day period would probably not he subject to that drawhack and would also encourage issuers to solicit proxies rather than just to comply with $\S 14(c)$.

200 Securities Exchange Act $\S 16$.

201 Securities Exchange Act $\$ 16(a)$.

202 Provisions allowing an issuer to recover short-term profits made by an insider in the issuer's stock and prohibiting short sales by an insider are not affected by the 1964 Amendments. Securities Exchange Act $\$ \S 16(\mathrm{~b}),(\mathrm{c})$. The exemption of arbitrage transactions from the other provisions of $\S 16$ is also continued. Securities Exchange Act $\S 16(\mathrm{e})$. 
ordinary course of his business and incident to the establishment or maintenance by him of a primary or secondary market" for a security. ${ }^{203}$ Without this section no insider would take on the risks of making a market since there would be no possibility of profit. In addition, underwriters of an issue claim that they have an obligation to be on the issuing company's board of directors so as to protect the investors while at the same time making a market in the stock so that investors will have a place to sell. ${ }^{204}$

Notwithstanding the reasons offered in support of exemption, the Special Study specifically objected to an exemption for market makers. ${ }^{205}$ The Study's data showed that in many cases the underwriter held no directorship and that some houses which had been underwriters continued to hold directorships but did not make a market in the stock. ${ }^{200}$ The Study also showed that where an underwriting firm wishing to keep its director's seat could not make a market, there were usually sufficient other market makers in the security to maintain its liquidity. ${ }^{207}$ Finally, the Study countered, with two arguments, the proposition that market makers needed a directorship to protect investors. First, many firms admitted they did not use inside information for this purpose. ${ }^{208}$ Second, the stocks involved would now be covered by the reporting and proxy provisions of the Exchange Act, so that investors would get directly the information formerly available only through the imvestment banker.

The exemption probably resulted from the support given it by the SEC. The SEC's recommendation sought to relieve investment banking louses from the cloice between giving up a directorship and abandoning profitable market-making activities. ${ }^{209}$ In view of the facts developed by the Special Study, the position of the Commission is unfortunate..$^{210}$

Another problem upon which Congress failed to act as a result of the

203 Securities Exchange Act $\S 16$ (d). While these terms have not yet been defined by SEC rules, they probably are intended to exempt sponsors and market makers. A sponsor makes a continuous market in a security. Special Study ch. IX, at 45 n.91. A market maker is prepared to buy and sell a stock, but only in limited amounts and not at all times. $I d$. at 45 and n.90. But cf. 17 C.F.R. \& 240.17a-9(f)(1) (1965). The original Senate bill contained an exemption for brokers as well as dealers. S. 1642, 88th Cong., 1st Sess. \& 8(b) (1964). But since a broker only effects transactions for the accounts of others, Securities Exchange Act $\S 3(\mathrm{a})(4)$, he cannot be liable under $\S 16$ and so does not need the protection of $\S 16(\mathrm{c})$.

204 Special Study ch. IX, at 43. Many corporations want an investment banker on their board of directors. Ibid.

205 Special Study ch. IX, at 63-64.

200 Special Study ch. IX, at 43, 48-49.

207 Special Study ch. IX, at 48.

208 Ibid.

209 House Hearings pt. 1, at 181.

$210 \mathrm{Cf}$. the supplemental dissent to the committee report. H.R. REP. 1418, 88th Cong., 2d Sess. 83 (1964). 
SEC position, ${ }^{211}$ is that posed by the decision in Blau v. Lehman. ${ }^{212}$ In Blau the Supreme Court held that a partnership is not liable under section 16 for insider profits though a member of the partnership was a director of the corporation, unless the partnership had deputed the partner-director to act for the partnership. As the Special Study pointed out, the decision ignored the realities of the business world; the Study recommended that the case be reversed by legislation. ${ }^{213}$ The SEC refused, however, to propose closing the looplole. SEC Clrairman Cary contended that judicial interpretation of "deputed" will close the gap. ${ }^{214}$ He also expressed fears that proposal of one change for section $16(\mathrm{~b})$ would lead to a discussion of all possible revisions of the section with the result that opponents of section 16(b) would be able to force Congress to adopt amendments which would weaken the section. ${ }^{215}$ Hopefully, the judiciary will fulfill the Chairman's first prediction.

\section{CONCLUSION}

Tlie Special Study of the Securities Markets provided the SEC with a highly persuasive basis for urging the passage of reform legislation. Moreover, the Congress had indicated receptiveness to such legislation by authorizing the Special Study. Congressional propensity to pass a strong bill was further increased by the unprincipled actions of certain exchange specialists following the assassination of President Kennedy. ${ }^{216}$

In light of those circumstances, the Securities Acts Amendments of 1964 are disappointing. As can be seen from the sections considered, the Amendments are interspersed with provisions unduly favoring special interests. These privileges did not result only from the power of lobbies such as those of the Comptroller of the Currency and the insurance industry. They also occurred because the SEC feared that by urging overly strenuous reforms, Congress would be driven to reject all of the Special Study's proposals. With the passage of time, however, the need to correct the deficiencies in the 1964 Amendments should become as clear as was the need to extend the Exchange Act to the OTC market.

Lee J. Sclar

211 See note 193 supra.

212368 U.S. 403 (1962).

213 Special Study ch. IX, at 64. The need for legislative action is also presented in Comment, 50 CaLIF. L. Rev. 500 (1962).

214 House Hearings pt. 2, at 1201.

215 House Hearings pt. 2, at 1200-02. Mr. Staggers' reply to Mr. Cary reads in part as follows: "I note that the commission and the securities industry reached an agreement that the Commission would not present to this committee any legislative recommendation in this field." House Hearings pt. 2, at 1202.

210 House Hearings pt. 2, at 1250. For example, in the falling market the specialists in American Photocopy made no purchases at all and sold 12,400 shares of which 4,800 were sold short. 